\title{
Chemical composition of Citrus spp. and oral antimicrobial effect of Citrus spp. peels essential oils against Streptococcus mutans
}

\author{
Dudi Aripin*, Euis Julaeha**, Murnisari Dardjan***, Arief Cahyanto**** \\ * Department of Conservative Dentistry, Faculty of Dentistry Universitas Padjadjaran, Indonesia \\ ** Department of Chemistry, Faculty of Mathematics and Natural Sciences Universitas Padjadjaran, \\ Indonesia \\ *** Department of Oral Biology, Faculty of Dentistry Universitas Padjadjaran, Indonesia \\ **** Department of Dental Materials Science and Technology, Faculty of Dentistry Universitas \\ Padjadjaran, Indonesia
}

\section{ABSTRACT}

Introduction: The essential oils of orange peels had a considerable potential to be used as an antimicrobial agent. The aim of this present study is to analized chemical composition of Citrus spp. And the oral antimicrobial effect of Citrus spp. peels essential oils against Streptococcus mutans. Methods: Five orange peels species were used in this study consist of Lime (Citrus aurantifolia), Tangerine (Citrus nobilis), Sweet Orange (Citrus sinensis), Lemon (Citrus limon), and Kaffir Lime (Citrus hystrix). The isolated essential oils were analyzed using gas chromatography-mass spectroscopy (GC-MS). The Streptococcus mutans ATCC 25175 was employed against the antimicrobial effect of samples. Results: The extraction yields of hydrodistilled-essential oils from Tangerine, Kaffir Lime, Sweet Orange, Lemon, and Lime provided the extraction yields of $4.20,2.26,1.97,1.74$ and $0.83 \%$ yields, respectively. Major component essential oils of Citrus spp. was D-Limonene. The highest antimicrobial activity against $\mathrm{S}$. mutans was Lime peel essential oil, followed by Lemon, Kaffir Lime, and Sweet Orange or Tangerine. All samples showed antimicrobial activity against $S$. mutans with the variation of antimicrobial action depending on the constituent of D-Limonene, B-Pinene, and a-terpineol. Conclusion: Major component chemical composition of essential oils of Citrus spp. was D-Limonene and antimicrobial activity by Lime peel essential oil due to its proportional amount of $D$-limonene and B-pinene and the highest antimicrobial activity.

Keywords: Citrus spp. essential oils, GC-MS, Streptococcus mutans, oral antimicrobial.

\section{INTRODUCTION}

Caries has been a health problem and remains the most prevalent chronic disease in children or adults. Dental caries is a disease of teeth hard tissue, e.g. enamel, dentin, and cementum due to the activity of microorganisms present in fermented carbohydrate. ${ }^{1}$ The bacteria in plaque attached to the tooth surface was the type of Streptococcus and Lactobacillus., ${ }^{2,3}$ The bacteria

Corresponding author: Euis Julaeha, Department of Chemistry, Faculty of Mathematics and Natural Sciences Universitas Padjadjaran, Indonesia. Jalan Sekeloa Selatan I, Bandung, West Java, Indonesia, 40132; Phone: +6222-2504985/2532805 
metabolized cariogenic food, mainly derived from the type of fermentable carbohydrates, such as sucrose, glucose, fructose, and maltose. ${ }^{4}$

Provision of fluoride toothpaste is an effective breakthrough combining both mechanical and chemical means to remove dental plaque. However, excess intake of fluoride may cause fluorosis in teeth and bones. Dental fluorosis is qualitative damage of tooth enamel as a result of an increased concentration of fluorine around ameloblast during the formation of tooth enamel and causes tooth discoloration. The tooth becomes pale and opaque or clinically visible as white-colored mottled enamel. In cases of severe fluorosis, the enamel turns brown and brittle, so called as mottled enamel. ${ }^{5}$ Therefore, the use of an active and additive substance with a low side effect is necessary.

The essential oil is one of the active materials that can be used to prevent microbial growth. The essential oil is a complex mixture of low molecular weight compounds extracted from plants by steam distillation or various solvents. Terpenoids and phenylpropanoid is a major component of which has a distinctive aroma and biological properties. Essential oils are used for a variety of health problems in traditional medicine systems, worldwide. Shankar et al., in 2014 reviewed various pharmaceutical and biological activities such as antimicrobial, antifungal, anticancer, antimutagenic, antidiabetic, antiviral, anti-inflammatory, and antiprotozoal of essential oils of various plant families included essential oils of Rutaceae family. ${ }^{6,7}$

Some research suggested that the essential oil of orange peels had a considerable potential for use as an antimicrobial material.8-20 Testing of antimicrobial activity against oral disease and dental bacteria, S. mutans in particular, have not been reported. Under these conditions, this study aimed at studying the effects of five essential oils of orange peel e.g. lime (C. aurantifolia), tangerine $(C$. nobilis), sweet orange ( $C$. sinensis), lemon $(C$. limon), and kaffir lime $(C$. hystrix) in inhibiting the growth of $S$. mutans.

The discovery of the potential and its effectiveness in inhibiting the growth of bacteria, essential oil was expected to be used as ingredients for oral and dental diseases. Thus, the problems faced by the community in terms of a toothache caused by cavities can be resolved. The result of this study was expected to contribute to the achievement of university research in the field of oral and dental health. The aim of this present study is to investigate the oral antimicrobial effect of Citrus spp. peels essential oils against Streptococcus mutans.

\section{METHODS}

Type of this research is invitro experiment. Five orange peels species were used in this study consist of lime (C. aurantifolia), tangerine (C. nobilis), sweet orange ( $C$. sinensis), lemon $(C$. limon), and kaffir lime ( $C$. hystrix) were collected from Caringin Central Market, Bandung, West Java, Indonesia.

The equipment used in this study included glassware commonly used in the organic chemistry laboratory. Other ancillary equipment consisted of distillation Stahl. For purposes of chemical constituents analysis of essential oil, gas chromatography-mass spectroscopy (GC-MSD, Brand of Agilent, Type 7890A GC, MSD Type 5975C) with 35MS DB column ( $35 \mathrm{~m}, 0.25 \mathrm{~mm}$ i.d., 0.25 $\mu \mathrm{m}$ film thickness), and MSD detector were used.

\section{Essential Oil Preparation}

The peel of Lime (C. aurantifolia), Tangerine ( $C$. nobilis), Sweet Orange (C. sinensis), Lemon ( $C$. limon), and Kaffir Lime ( $C$. hystrix) was cleaned, peeled, and cut into $\pm 2 \mathrm{~cm}$ in order to get sufficient amount of extraction yield. Hydrodistillation for 8 hours was conducted to obtain essential oils.

\section{GC-MSD Measurement}

Chemical composition and quality of essential oils may be varied depending on climate and soil, the maturity of the fruit, the extraction technique and storage time. The chemical composition of essential oils varied depending on the environmental conditions of the plant, even within the same species.

The chemical composition of orange peel essential oil consists mainly of hydrocarbon, alcohol, ester, aldehyde, ketone, lactone oxidized, sulfur, nitrogen compound and nonvolatile compounds. The composition depended on environmental condition and genetic factors 
that would produce the enzyme systems that are typical of the glandular arrangement. The analysis of chemical constituents of essential oil was performed on Gas Chromatography-Mass Spectrophotometry (GC-MS).

The analysis of chemical constituents of essential oils was performed on Gas Chromatography-Mass Spectrophotometry (GCMSD) Brand Agilent (GC Type 7890A, MSD Type 5975C). A column used was DB 35MS with column length of $35 \mathrm{~m}$, internal diameter of $0.25 \mathrm{~mm}$, film thickness of $0.25 \mu \mathrm{m}$, and a MSD detector. Temperature program in operation was as follows: the initial temperature was $50^{\circ} \mathrm{C}$ for 1 minute, followed by temperature increase $50-250^{\circ} \mathrm{C}$ at a flow rate of $3.5^{\circ} \mathrm{C} /$ minute. As much as $1 \mu \mathrm{L}$ Citrus spp. essential oils was injected in $0.5 \%$ concentration with an injector temperature of $250^{\circ} \mathrm{C} .25$

Kirby Bauer Antimicrobial Activity Method Test Bacterial Rejuvenation

A stock of S. mutans ATCC 25175 was inoculated into a sterile test tube containing physiological saline suspension as much as $4 \mathrm{~mL}$ to reach the level of turbidity $1 / 2$ Mac Farland. Furthermore, the test tube was then incubated for $2 \times 16-18$ hours at $37^{\circ} \mathrm{C}$.

\section{Antimicrobial Activity}

Cotton sticks dipped in bacterial suspension were then applied to the surface of the agar medium until evenly distributed. A total of five samples $50 \mu \mathrm{L}$ essential oils, a positive control (antibiotic) and a negative control (methanol) dropped on paper samir (disk) is then placed on blood agar medium, then incubated at $37^{\circ} \mathrm{C}$ for 2 x 24 hours. After $2 \times 24$ hours, the diameter of a clear zone around the wells was observed and measured using a caliper.

\section{RESULTS}

\section{Essential oils extraction}

Essential oils were obtained from peels of some orange fruits by hydrodistillation technique for eight hours, conducted multiple times to reach sufficient amount. The extraction yields of hydrodistilled-essential oils from each peel of Citrus spp. widely varied. Tangerine (C. nobilis), Kaffir Lime ( $C$. hystrix), Sweet Orange ( $C$. sinensis), Lemon ( $C$. Limon), and Lime ( $C$. aurantifolia) provided the extraction yields of $4.20,2.26,1.97$, 1.74 and $0.83 \%$ yield, respectively.

\section{Chemical Composition of Lime Peel Essential Oil (C. aurantifolia)}

The chromatogram of Lime peel essential oils (C. aurantifolia) was shown in fig. 1 . The identity of the components in Lime peel ( $C$. aurantifolia) essential oils was assigned by matching their spectral data with those detailed in the NIST11.L libraries which are given in table 2.

Table 2 summarized that the major component essential oils of Lime peel (C. aurantifolia) was D-Limonene $\left(R_{t}=10.445 \mathrm{~min}\right.$, peak area of $38.94 \%)$, B-Pinene $\left(R_{t}=8.334 \mathrm{~min}\right.$, peak area of $26.66 \%$ ), and other components had peak area below $5 \%$.

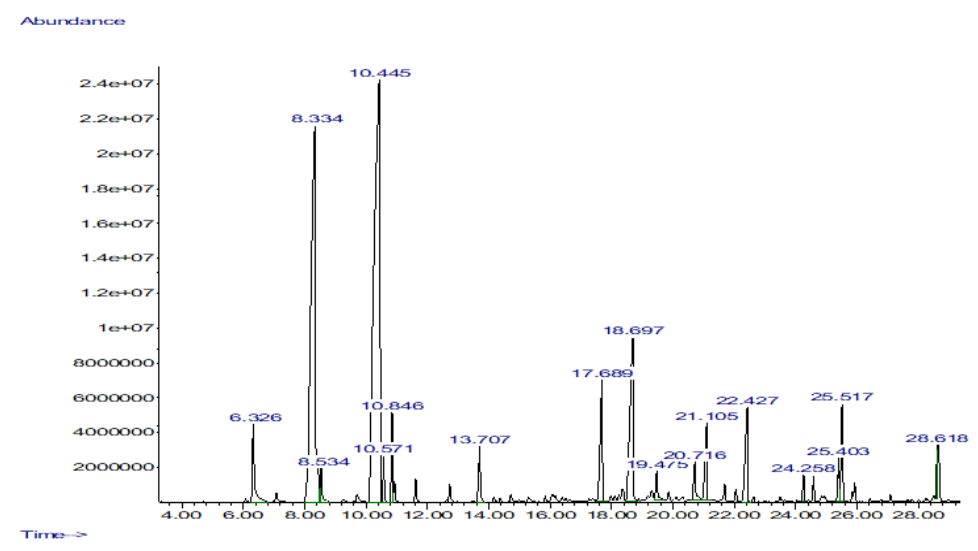

Figure 1. GC chromatogram of lime peel essential oil (c. Aurantifolia) 
Table 2: chemical composition of lime peel essential oil (c. Aurantifolia)

\begin{tabular}{|c|c|c|c|c|}
\hline No. & Retention time $\left(R_{t}\right)$ (minute) & Peak area(\%) & Compounds & Quality \\
\hline 1. & 6.326 & 2.79 & (1R)-2,6,6-trimethylbicyclo[3.1.1] hept-2-ena & 96 \\
\hline 2. & 8.334 & 26.66 & B-Pinene & 95 \\
\hline 3. & 8.534 & 0.92 & B-Mircene & 91 \\
\hline 4. & 10.445 & 38.94 & D-Limonene & 96 \\
\hline 5. & 10.571 & 0.94 & B-Phellandren & 91 \\
\hline 6. & 10.846 & 1.88 & o-Simene & 97 \\
\hline 7. & 13.707 & 1.67 & 1,6-Octadiene-3-ol, 3,7-dimethyl- & 97 \\
\hline 8. & 17.689 & 4.32 & Terpinen-4-ol & 95 \\
\hline 9. & 18.697 & 8.29 & a-Terpineol & 86 \\
\hline 10. & 19.475 & 0.88 & 2,6-Octadien-1-ol, 3,7-dimethyl-, (Z) & 96 \\
\hline 11. & 20.716 & 1.26 & Geraniol & 97 \\
\hline 12. & 21.105 & 2.61 & 2,6-Octadienal, 3,7-dimethyl-, (Z) & 93 \\
\hline 13. & 22.427 & 3.61 & Cytrale & 96 \\
\hline 14. & 24.258 & 0.65 & $\begin{array}{l}\text { Cyclohexane, 1-etenil-1-methyl-2, 4-bis(1-methyletenil)-, } \\
{[1 \mathrm{~S}-(1 \mathrm{a}, 2 \mathrm{~B}, 4 \mathrm{~B})]-}\end{array}$ & 91 \\
\hline 15. & 25.403 & 1.05 & Bicyclo[3.1.1]hept-2-ena, 2,6-dimethyl-6-(4-methyl-3-pentenyl)- & 97 \\
\hline 16. & 25.517 & 2.57 & Geranyl acetate & 74 \\
\hline 17. & 28.618 & 0.98 & B-Bisabolene & 93 \\
\hline
\end{tabular}

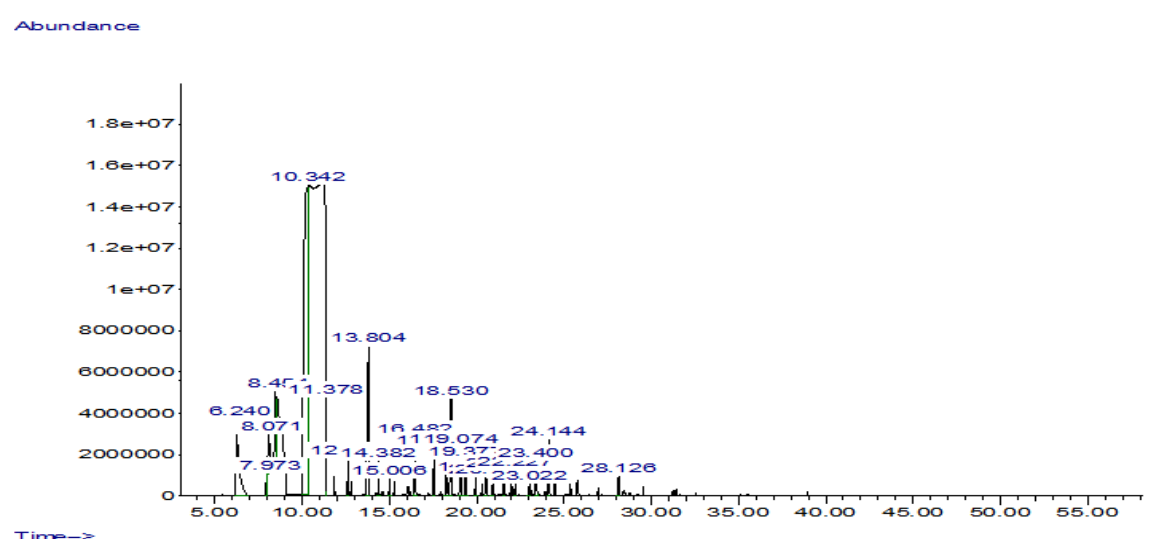

Figure 2: gc chromatogram of tangerine peel essential oil (c. Nobilis)

\section{Chemical composition of tangerine peel essential} oil (C. nobilis)

The GC chromatogram of Tangerine peel essential oils ( $C$. nobilis) was shown in fig. 2. Table 3 showed the components in Tangerine peel essential oil which was assigned by matching their spectral data with those detailed in the NIST11.L libraries. Table 3 summarized that the major component essential oils of Tangerine peel ( $C$. nobilis) was $\mathrm{D}$-Limonene $\left(\mathbf{R}_{t}=10.342 \mathrm{~min}\right.$, peak area of $50.06 \%$ ), and other components had peak area below $10 \%$.

\section{Chemical composition of sweet orange essential} oil (C. sinensis)

The GC chromatogram of sweet orange peel essential oils $(C$. sinensis) was shown in fig. 3. Table 4 showed that the components in Sweet Orange ( $C$. sinensis) peel essential oil which was assigned by matching their spectral data with those detailed in the NIST11.L libraries.

Table 4 summarized that the major component essential oils of Sweet Orange peel ( $C$. sinensis) was $D$-Limonene $\left(\mathbf{R}_{t}=10.354 \mathrm{~min}\right.$, peak area of 21.74\%), 1,6-octadiene-3-ol, 3,7-dimethyl- 
Table 3: chemical composition of tangerine peel essential oil (c. Nobilis)

\begin{tabular}{|c|c|c|c|c|}
\hline No. & Retention time $\left(\mathrm{R}_{\mathrm{t}}\right)$ (minute) & Peak area(\%) & Compounds & Quality \\
\hline 1. & 6,240 & 7.81 & (1S)-2,6,6-trimethylbicyclo[3.1.1] hept-2-ene & 96 \\
\hline 2. & 7.973 & 0.70 & B-Phellandrene & 94 \\
\hline 3. & 8.071 & 3.69 & B-Pinene & 91 \\
\hline 4. & 8.454 & 4.57 & B-Mircene & 80 \\
\hline 5. & 10.342 & 50.06 & D-Limonene & 96 \\
\hline 6. & 11.378 & 1.37 & B -Osimene & 96 \\
\hline 7. & 12.637 & 1.16 & Cyclooctene & 90 \\
\hline 8. & 13.804 & 8.47 & 1,6-Octadien-3-ol, 3,7-dimethyl- & 97 \\
\hline 9. & 14.382 & 1.00 & Nonanal & 86 \\
\hline 10. & 15.006 & 0.51 & 1,3,8-p-Mentatriene & 97 \\
\hline 11. & 16.482 & 2.18 & Citronellal & 94 \\
\hline 12. & 17.558 & 1.51 & Terpinen-4-ol & 95 \\
\hline 13. & 18.273 & 1.88 & Dekanal & 91 \\
\hline 14. & 18.530 & 4.05 & a-Terpineol & 86 \\
\hline 15. & 19.074 & 1.98 & Sitronelol & 96 \\
\hline 16. & 19.377 & 1.19 & 2,6-Octadiene-1-ol, 3,7-dimethyl-, (Z) & 96 \\
\hline 17. & 19.932 & 0.70 & trans-Carveol & 87 \\
\hline 18. & 20.533 & 0.75 & Geraniol & 95 \\
\hline 19. & 20.928 & 0.58 & Cytrale & 72 \\
\hline 20. & 21.563 & 0.79 & $\begin{array}{l}\text { Cycloheksene, 4-etenyl-4-methyl-3, (1-methyletenyl)-1-(1- } \\
\text { methyletil)-, (3R-trans)- }\end{array}$ & 96 \\
\hline 21. & 22.227 & 0.82 & Cytrale & 95 \\
\hline 22. & 23.022 & 0.50 & p-Menta-1(7),8(10)-dien-9-ol & 30 \\
\hline 23. & 23.400 & 1.21 & 1-Cyclohexena-1-carboxaldehida, 4- (1-methyletil)- & 96 \\
\hline 24. & 24.144 & 1.82 & $\begin{array}{l}\text { Cyclohexanea, 1-etenyl-1-methyl-2, 4-bis(1-methyletil)-, } \\
\text { [1S-(1a,2B,4 B }\end{array}$ & 96 \\
\hline 25. & 28.126 & 0.69 & $\begin{array}{l}\text { 1,6-Cyclodekadiena,1-methyl-5-metilen-8-(1-methyletil)-, } \\
{[S-(E, E)]-}\end{array}$ & 96 \\
\hline
\end{tabular}

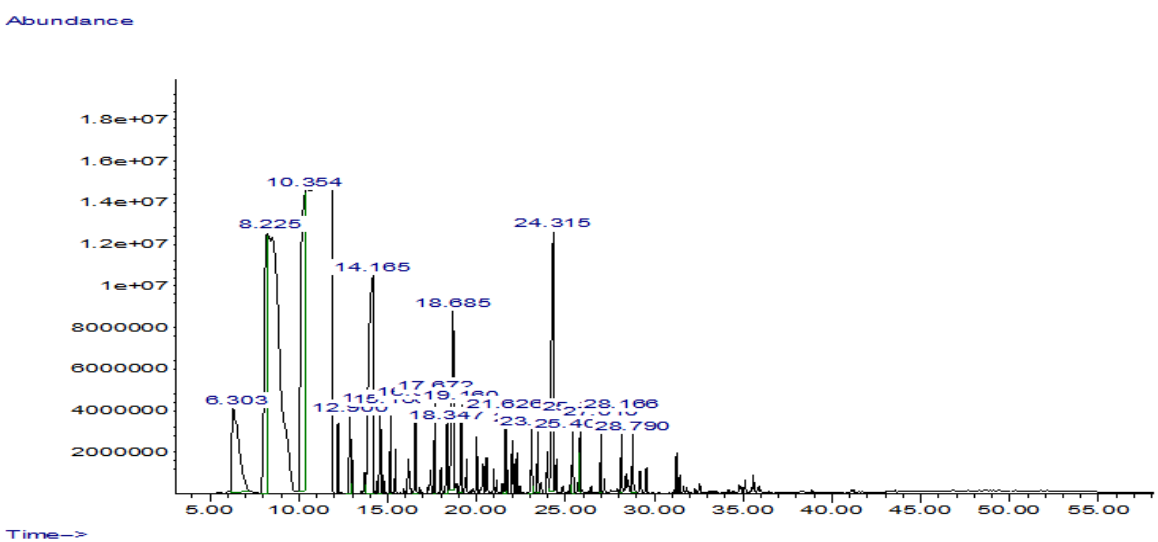

Figure 3. GC chromatogram of sweet orange peel essential oil (c. Sinensis)

$\left(\mathbf{R}_{t}=14.165 \mathrm{~min}\right.$, peak area of $\left.14.165 \%\right)$, B-pinene $\left(\mathbf{R}_{t}=8.225 \mathrm{~min}\right.$, peak area of $\left.15.37 \%\right)$ and other components had peak area below $11 \%$.
Composition of lemon peel essential oil (C. limon) The GC chromatogram Lemon (C. limon) peel essential oil was given in fig. 4. Table 5 
Table 4: chemical composition of sweet orange essential oil (c. Sinensis)

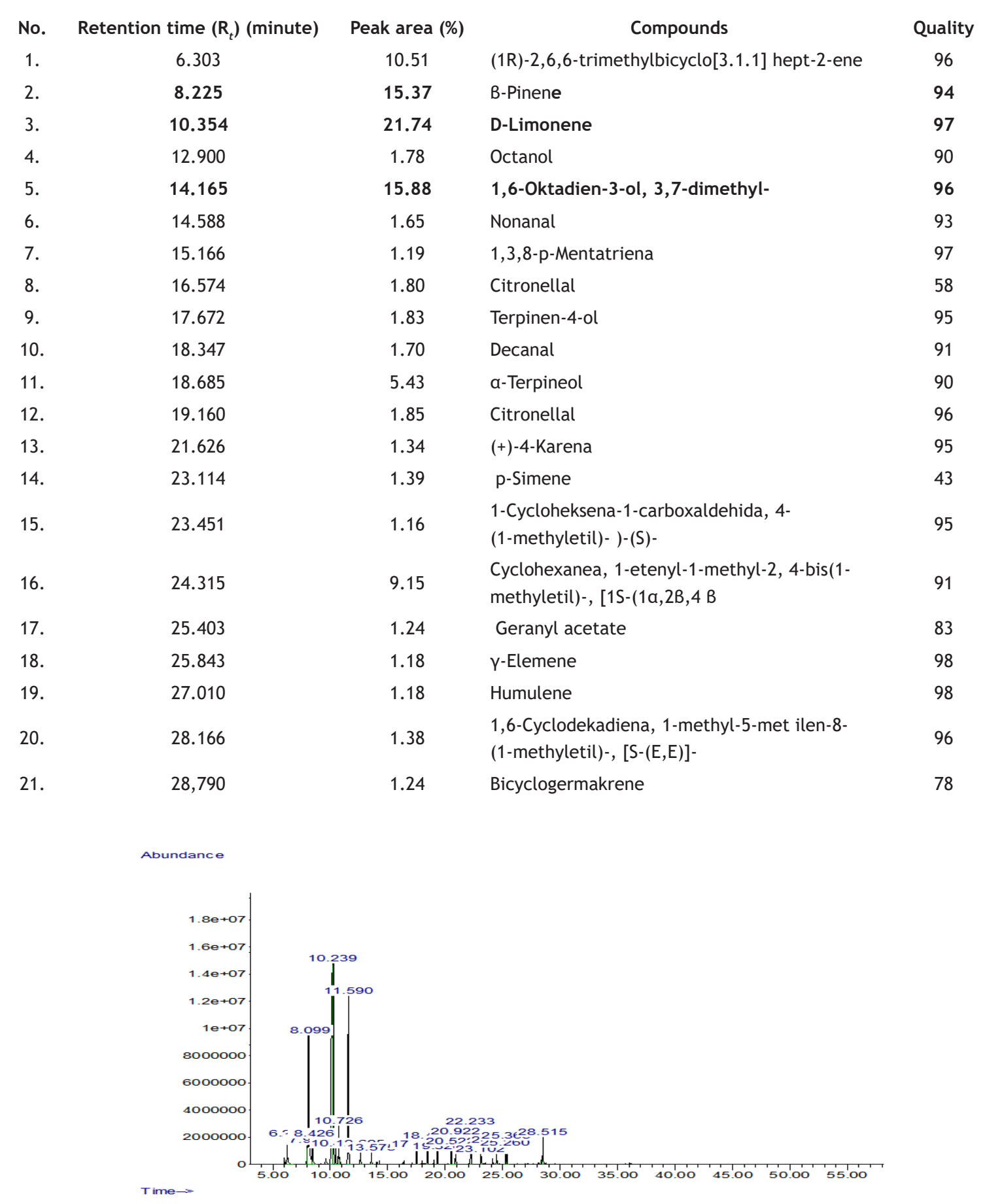

Figure 4: gc chromatogram of lemon peel essential oil (c. Limon)

showed the components in Lemon (C. limon) peel essential oils which were assigned by matching their spectral data with those detailed in the NIST11.L libraries.

Table 5 summarized that the major component of Lemon (C. limon) peel essential oils was $\mathrm{D}$-Limonene $\left(\mathbf{R}_{\boldsymbol{t}}=10.239 \mathrm{~min}\right.$, peak area of $41.36 \%), \gamma$-Terpinene $\left(\mathbf{R}_{t}=11.590 \mathrm{~min}\right.$, peak area of $16.87 \%)$, B-Pinene $\left(\mathbf{R}_{t}=8.0995 \mathrm{~min}\right.$, peak area of $14.16 \%$ ) and other components had peak area below $5 \%$.

\section{Chemical Composition of Kaffir Lime Essential} Oil (C. hystrix)

The GC chromatogram of Kaffir Lime ( $C$. hystrix) peel essential oils is given in fig. 5. Table 
Table 5: chemical composition of lemon essential oil (c. Limon)

\begin{tabular}{|c|c|c|c|c|}
\hline No. & Retention time $\left(\mathbf{R}_{t}\right)$ (minute) & Peak area $(\%)$ & Compounds & Qualit \\
\hline 1. & 6.240 & 2.43 & $\begin{array}{l}(1 \mathrm{R})-2,6,6 \text {-trimethylbicyclo[3.1.1] } \\
\text { hept-2-ene }\end{array}$ & 97 \\
\hline 2. & 7.979 & 1.43 & B-Phellandrene & 94 \\
\hline 3. & 8.099 & 14.16 & B-Pinene & 94 \\
\hline 4. & 8.426 & 2.35 & B-Mircene & 86 \\
\hline 5. & 10.239 & 41.36 & D-Limonene & 97 \\
\hline 6. & 10.451 & 0.95 & $\begin{array}{l}\text { Bicyclo[3.1.0]hept-2-ena, 4-methyl-1-(1- } \\
\text { methyletil)- }\end{array}$ & 91 \\
\hline 7. & 10.726 & 2.34 & o-Simen & 97 \\
\hline 8. & 11.590 & 16.87 & $\gamma$-Terpinene & 94 \\
\hline 9. & 12.625 & 1.16 & $\begin{array}{l}\text { Cycloheksena, 1-methyl-4-(methyletillide } \\
\text { na)- }\end{array}$ & 96 \\
\hline 10. & 13.575 & 0.86 & 1,6-Oktadien-3-ol, 3,7-dimethyl- & 97 \\
\hline 11. & 17.495 & 1.12 & $\begin{array}{l}\text { 3-Cycloheksen-1-ol, 4-methyl-1- } \\
\text { (1-methyletil)-, (R)- }\end{array}$ & 97 \\
\hline 12. & 18.433 & 1.65 & a-Terpineol & 80 \\
\hline 13. & 19.320 & 0.87 & 2,6-Oktadien-1-ol, 3,7-dimethyl-, (Z) & 96 \\
\hline 14. & 20.522 & 1.32 & Geraniol & 97 \\
\hline 15. & 20.922 & 1.82 & 2,6-Octadienal, 3,7-dimethyl-, (Z) & 76 \\
\hline 16. & 22.233 & 2.68 & Cytrale & 97 \\
\hline 17. & 23.102 & 0.90 & Timol & 95 \\
\hline 18. & 24.464 & 1.22 & 2,6-Octadien-1-ol,3,7-dimethyl-asetat, (Z)- & 91 \\
\hline 19. & 25.260 & 1.08 & $\begin{array}{l}\text { 1,3,6,10-Dodekatetraen-3,7,11- } \\
\text { trimethyl-, (Z,E)- }\end{array}$ & 94 \\
\hline 20. & 25.363 & 1.70 & Geranyl acetate & 68 \\
\hline 21. & 28,515 & 1.74 & B-Bisabolen & 96 \\
\hline
\end{tabular}

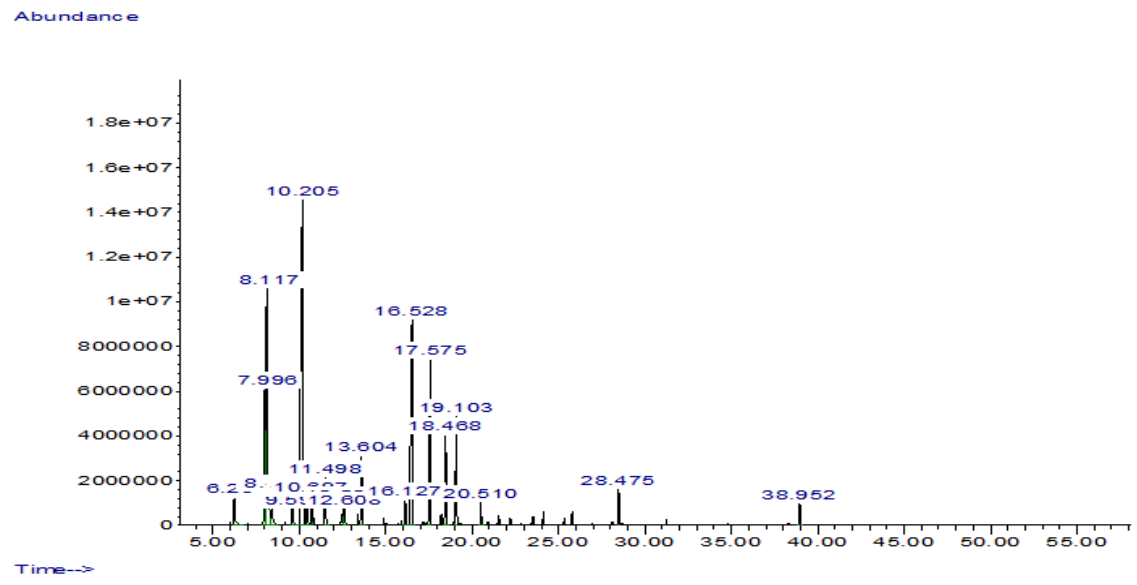

Figure 5: gc chromatogram of kaffir lime peel essential oil (c. Hystrix)

6 showed the components in Kaffir Lime ( $C$. hystrix) peel essential oils which were assigned by matching their spectral data with those detailed in the NIST11.L libraries. Table 6 summarized that the major component of Kaffir Lime (C. hystrix) peel essential oils was D-Limonene $\left(\mathbf{R}_{t}=10.205\right.$ min, peak area of 31.24\%), B-pinene $\left(R_{t}=8.117\right.$ min, peak area of $13.81 \%)$, citronellal $\left(R_{t}=16.528\right.$ min, peak area of $13.41 \%$ ) and other components had peak area below $5 \%$. 
Table 6: chemical composition of kaffir lime essential oil (c. Hystrix)

\begin{tabular}{|c|c|c|c|c|}
\hline No. & Retention time $\left(\mathbf{R}_{t}\right)$ (minute) & Peak area (\%) & Compounds & Quality \\
\hline 1. & 6.234 & 1.46 & (1R)-2,6,6-trimethylbicyclo[3.1.1] hept-2-ene & 96 \\
\hline 2. & 7.996 & 7.18 & Bicyclo[3.1.0]hexana, 4-methylene-1-(1-methyletil)- & 91 \\
\hline 3. & 8.117 & 13.81 & B-Pinene & 94 \\
\hline 4. & 8.420 & 1.50 & B-Mircene & $90-$ \\
\hline 5. & 7.979 & 1,43 & Cyclohexene, 1-methyl-4-(methyletillidene)- & 94 \\
\hline 6. & 10.205 & 31.24 & D-Limonene & 97 \\
\hline 7. & 10.388 & 1.47 & B-Phellandrene & 91 \\
\hline 8. & 10.697 & 0.98 & o-Simene & 97 \\
\hline 9. & 11.498 & 2.00 & $\gamma$-Terpinene & 95 \\
\hline 10. & 12.522 & 0.66 & $\begin{array}{l}\text { Ethyl 2-(5-methyl-5-viniltetrahidrofuran } \\
\text { propan-2-il carbamate }\end{array}$ & 91 \\
\hline 11. & 12.608 & 0.70 & 3-Karen & 94 \\
\hline 12. & 13.604 & 2.96 & 1,6-Octadien-3-ol, 3,7-dimethyl- & 97 \\
\hline 13. & 16.127 & 1.22 & $\mathrm{dl}$-Isopulegol & 98 \\
\hline 14. & 16.528 & 13.41 & Citronellal & 95 \\
\hline 15. & 17.575 & 8.28 & Terpinen-4-ol & 95 \\
\hline 16. & 18.468 & 3.63 & a-Terpineol & 86 \\
\hline 17. & 19.103 & 5.62 & Citronellol & 98 \\
\hline 18. & 20.510 & 0.88 & 2,6-Oktadien-1-ol, 3,7-dimethyl-, (Z) & 94 \\
\hline 19. & 28.475 & 1.21 & a -Farnesen & 93 \\
\hline 20. & 38.952 & 0.86 & 2,6,9,11-Dodekatetraenal, 2,6,10- trimethyl-, (E,E,E)- & 90 \\
\hline
\end{tabular}

Table 7: diameter of inhibition zone against s. Mutans

\begin{tabular}{clccc}
\hline No. & \multicolumn{1}{c}{ Essential Oil } & Diameter $(\mathrm{mm})$ of inhibition zone against S. mutans & Average $(\mathrm{mm})$ \\
\hline 1. & Lime (C. aurantifolia) & 10.40 & 11.20 & 11.20 \\
2. & Tangerine (C. nobilis) & 9.55 & 10.65 & 10.65 \\
3. & Sweet Orange (C. sinensis) & 10.20 & 10.00 & 10.00 \\
4. & Lemon (C. limon) & 10.50 & 10.50 & 10.50 \\
5. & Kaffir Lime (C. hystrix) & 10.40 & 10.40 & 10.40 \\
6. & Negative Control (DMSO) & 8.90 & 9.00 & 9.00 \\
7. & Positive Control* (Chlorhexidin) & 17.85 & 17.85 & 17.85 \\
\hline
\end{tabular}

Antimicrobial activity of citrus spp. Essential oils

All hydrodistilled-essential oils of citrus peels from five citruses in 20\% ( $\mathrm{v} / \mathrm{v})$ concentration were tested for antimicrobial activity against $\mathrm{S}$. mutans and the result shows in table 7. Table 7 showed that Lime peel (C. aurantifolia) have the highest antibacterial activity against $S$. mutans, followed by Lemon (C. limon), Kaffir Lime ( $C$. hystrix), and Sweet Orange ( $C$. sinensis)/Tangerine (C. nobilis).

The relationship between Antimicrobial Activity and Chemical Composition of Citrus Spp. Essential Oils
The chemical constituents of the essential oils of all types of Citrus spp. peel was mostly similar despite the difference in compositions. This caused the aroma of each orange peel essential oil had its own peculiarities. Various constituents and compositions led to differences in inhibitory effect against the growth of bacteria S. mutans, as shown in table 8 . Table 8 showed that the three main components of all Citrus spp. peel essential oil was D-Limonene, B-Pinene, with three different components for the five kinds of essential oils. Tangerine peel oil contained the least B-Pinene compared to the four others citrus peel essential oil. The chemical composition that 
Table 8: diameter of inhibition zone against s. Mutans

\begin{tabular}{|c|c|c|c|c|c|}
\hline \multirow{2}{*}{ No. } & \multirow{2}{*}{ Essential Oil } & \multicolumn{3}{|c|}{ Main Component and Peak Area (\%) } & \multirow{2}{*}{$\begin{array}{c}\text { Inhibitory } \\
\text { Diameter }(\mathrm{mm})\end{array}$} \\
\hline & & 1 & 2 & 3 & \\
\hline 1. & Lime (C. aurantifolia) & D-Limonene (38.94) & B-Pinene $(26.66)$ & a-Terpineol (8.29) & 10.80 \\
\hline 2. & Tangerine (C. nobilis) & D-Limonene $(50.06)$ & $\begin{array}{l}\text { 1,6 Oktadien-3-ol, } \\
\text { 3,7-dimethyl- } \quad(8.47)\end{array}$ & $\begin{array}{l}\text { (1S)-2,6,6-trimethyl bisiklo } \\
\text { [3.1.1] hept-2-ena }(7.81)\end{array}$ & 10.10 \\
\hline 3. & $\begin{array}{l}\text { Sweet Orange }(C . \\
\text { sinensis })\end{array}$ & D-Limonene (21.74) & $\begin{array}{lr}\text { 1,6-Oktadien } & -3-\mathrm{ol}, \\
\text { 3,7-dimethyl- } & (15.88)\end{array}$ & B-Pinene (15.37) & 10.10 \\
\hline 4. & Lemon (C. limon) & D-Limonene (41.36) & $\mathrm{Y}$-Terpinene $(16.87)$ & B-Pinene (14.16) & 10.50 \\
\hline 5. & Kaffir Lime (C. hystrix) & D-Limonene (31.24) & B-Pinene (13.81) & Citronellal (13.41) & 10.40 \\
\hline
\end{tabular}

Table 9: d-limonene, B-pinene, and a-terpineol composition of citrus spp. Essential oils and its inhibitory effect on s. Mutans

\begin{tabular}{clcccc}
\hline \multirow{2}{*}{ No. } & \multirow{2}{*}{ Essential Oil } & \multicolumn{3}{c}{ Peak Area (\%) } & \multirow{2}{*}{ Inhibitory Diameter (mm) } \\
\cline { 3 - 5 } & & D-Limonene & B-Pinene & a-Terpineol & 10.80 \\
\hline 1. & Lime (C. aurantifolia) & 38.94 & 26.66 & 8.29 & 10.50 \\
2. & Lemon (C. limon) & 41.36 & 14.16 & 1.65 & 10.40 \\
3. & Kaffir Lime (C. hystrix) & 31.24 & 13.81 & 3.63 & 10.10 \\
4. & Sweet Orange (C. sinensis) & 21.74 & 15.37 & 5.43 & 10.10 \\
5. & Tangerine (C. nobilis) & 50.06 & 3.69 & 4.05 & \\
\hline
\end{tabular}

playing a role in inhibiting of $S$. mutans growth was D-Limonene and B-Pinene. Tangerine peel oil contained the highest D-Limonene, however, it possessed the lowest activity since the content of $B$-Pinene was very low. The highest activity was shown by lime peel essential oil (C. aurantifolia) containing proportional amount of D-Limonene and B-pinene. Table 9 summarized that the order of antimicrobial activity of the five essential oils of orange peel and composition of D-Limonene, B-pinene, and a-Terpineol. The inhibitory activity of essential oils against $S$. mutans reached effectiveness at proportional compositions of $\mathrm{D}$-Limonene and B-Pinene with a high peak area of a-terpineol.

\section{DISCUSSION}

The essential oil has been widely used for a variety of health problems and was reviewed to possess various advantageous biological properties including antimicrobial properties. Essential oils of Rutaceae (orange) family have been reported to be significant as an antimicrobial agent. The result of this study showed that all the essential oils of orange peel were potential in inhibiting growth of S. mutans with the following inhibitory zone diameter value of: (1) Lime (C. aurantifolia)
$10.80 \mathrm{~mm}$; (2) Tangerine (C. nobilis) $10.10 \mathrm{~mm}$ (3) Sweet Orange (C. sinensis) $10.10 \mathrm{~mm}$; (4) lemon (C. limon) $10.50 \mathrm{~mm}$; and (5) Kaffir Lime (C. hystrix) $10.40 \mathrm{~mm}$. Lime essential oil was the most effective to inhibit the growth of $S$. mutans among other Citrus spp. This result was consistent with a previous study conducted by Suwondo S. (2007) that screened 30 types of plants and tested its activity against $S$. mutans serotype- $C$ and serotype-d, which obtained that lime (C. aurantifolia) was active against both serotypes. It was also shown that the least effective Citrus spp. peel essential oil against $S$. mutans was Tangerine (C. nobilis) and Sweet Orange (C. sinensis). Another previous study also showed that essential oil of orange showed the lowest antibacterial activity compared to bergamot and lemon. ${ }^{21}$

Citrus spp. essential oils presented moderate antimicrobial activity against $\mathrm{S}$. mutans, facultative anaerobic gram-positive bacteria, with inhibition diameter value between $10.10 \mathrm{~mm}$ and $10.80 \mathrm{~mm}$. A similar study on gram positive bacteria showed that orange peel essential oil was more sensitive to gram-positive bacteria compared to gram-negative bacteria such as Salmonella enteritidis and Escherichia coli. ${ }^{21,22}$

The chemical constituents of Citrus spp. peel essential oil was mostly similar, with the main 
composition of D-Limonene and B-Pinene, despite the difference in compositions. D-Limonene is the major component of Citrus spp., however, the correlation between the D-Limonene content in each essential oil and its antibacterial activity was not significant. Tangerine ( $C$. nobilis) contained the highest limonene, however, it was less effective as an antimicrobial than other four essential oils with less limonene content. It was in line with studies showing that compounds presented in larger proportions may not necessarily be responsible for the antimicrobial activity of essential oils and the consideration of the less abundant constituents was necessary. ${ }^{22,23}$ The presence of minor compounds may increase antimicrobial activity of essential oils due to the synergy between each major and minor components on proportional concentration that may lead to the achievement of obtaining effective antimicrobial activity. ${ }^{23,24}$

Comparison of efficacy between essential oils within similar species was difficult to be conducted, considering the environmentally-dependent chemical composition and its constituents ratio resulting in variation of antimicrobial activities. Major and minor constituents ratio were influenced widely by genotypes, while antimicrobial activity was sensitive technique resulting in conflicting results among studies. Further study of antimicrobial activity of Citrus spp. essential oils focusing on obtaining minimum inhibitory concentration (MIC) and minimum bactericidal concentration $(M B C)$ of all five Citrus spp. essential oils against $S$. mutans were necessary to be conducted in order to obtain the purpose of this study.

\section{CONCLUSION}

Major component chemical composition of essential oils of Citrus spp. was D-Limonene and antimicrobial activity by Lime peel essential oil due to its proportional amount of D-limonene and $B$-pinene and the highest antimicrobial activity.

\section{ACKNOWLEDGMENT}

The authors are grateful to Faculty of Dentistry, Universitas Padjadjaran, Indonesia for funding under internal grant research and supporting this study.

\section{REFERENCES}

1. Besra M, Kumar V. Antimicrobial activity of essential oils and herbal extracts against etiological agent of dental caries. J Essent Oil Bear PLant 2016;19(7):1807-15.

2. Yu OY, Zhao IS, Mei ML, Lo EC-M, Chu CH. Dental biofilm and laboratory microbial culture models for cariology research. Dent J 2017;5:21.

3. Daboor SM, Farheen SSM, Marwa SA, Elbagir EN. A review on Streptococcus mutans with its diseases dental caries, dental plaque and endocarditis. Indian J Microbial Res 2015;2(2):76-82.

4. Touger-Decker R, Van Loveren C. Sugars and dental caries. Am J Clin Nutr 2003;78(4):881S-892S.

5. Steiner M, Menghini G, Thomet E, Jager A, Pfister J, Imfeld T. Assesment of dental fluorosis prevalence in Swiss populations. Schweiz Monatsschr Zahnmed 2010;120(1):1220.

6. Shankar RJ, Mohan KS. A status review on the medicinal properties of essential oils. Ind Crops Prod 2014;62:250-64.

7. Palazzolo E, Laudicina VA, Germanà MA. Current and potential use of citrus essential oils. Curr Org Chem 2013;17:3042-49.

8. Babpour E, Angaji SA, Angaji SM. Antimicrobial effects of four medicinal plants on dental Plaque. J Med Plants Res 2009;3(3):132-7.

9. Acar U, Sabri Kesbiç O, Yılmaz S, Nejdet G, Türker A. Evaluation of the effects of essential oil extracted from sweet orange peel (Citrus sinensis) on growth rate of tilapia (Oreochromis mossambicus) and possible disease resistance against Streptococcus iniae. Aquaculture 2015;437:282-6.

10. Choi O, Cho SK, Kim J, Park CG, Kim J. In vitro antibacterial activity and major bioactive components of Cinnamomum verum essential oils against cariogenic bacteria, Streptococcus mutans and Streptococcus sobrinus. Asian Pac J Trop Biomed 2016;6(4):308-14.

11. Freires IA, Denny C, Benso B, Alencar SMD, Rosalen PL. Antibacterial activity of essential oils and their isolated constituents against cariogenic bacteria: A systematic review. 
Molecules 2015;20:7329-58.

12. Gauniyal P, Teotia UVS. Evaluation of antimicrobial activity and phytochemical screening of twenty medicinal plants against oral microbes. Int $\mathrm{J}$ of Multidiscip Curr Res 2015;3(6):427-36.

13. Islam TH, Azad AHB, Akter S, Datta $S$. Antimicrobial activity of medicinal plants on Streptococcus mutans, a causing agent of dental caries. Int J Eng Res Tech 2012;1(10):16.

14. Jebashree HS, Kingsley SJ, Sathish ES, Devapriya D. Antimicrobial activity of few medicinal plants against clinically isolated human cariogenic pathogens - an in vitro study. ISRN Dent 2011;1:1-6.

15. Oliveira SAC, Zambrana JRM, lorio FBR, Pereira $C A$, Jorge $A O C$. The antimicrobial effects of Citrus limonum and Citrus aurantium essential oils on multi-species biofilms. Braz Oral Res 2013;28(1):1-6.

16. Saeb S, Amin M, Gooybari RS, Aghel N. Evaluation of antibacterial activities of citrus limon, citrus reticulata, and citrus grandis against pathogenic bacteria. Int J Enteric Pathog 2016;4(4):e37103.

17. Shetty SB, Ismail PMS, Varghese S, George BT, Thajuraj PK, Baby D, et al. Antimicrobial effects of Citrus sinensis peel extracts against dental caries bacteria: an in vitro study. J Clin Exp Dent 2016;8(1):e71-7.
18. Rivera CJ, Crandall PG, O’Bryan CA, Ricke SC. Essential oils as antimicrobials in food systems - A review. Food Control 2015;54:111-9.

19. Thosar N, Basak S, Bahadure RN, Rajurkar M. Antimicrobial efficacy of five essential oils against oral pathogens: an in vitro study. Eur J Dent 2013;7(1):71-7.

20. Vasek OM, Cáceres LM, Chamorro ER, Velasco GA. Antibacterial activity of Citrus paradisi essential oil. J Nat Prod 2015;8:16-26.

21. Djenane D. Chemical profile, antibacterial and antioxidant activity of algerian citrus essential oils and their application in sardina pilchardus. Foods2015;4:208-28.

22. Chouhan S, Sharma K, Guleria S. Antimicrobial activity of some essential oils-present status and future perspectives. Medicines 2017;4(3):58.

23. Nazzaro F, Fratianni F, De Martino L, Coppola R, De Feo V. Effect of essential oils on pathogenic bacteria. Pharmaceuticals 2013;6(12):1451-74.

24. Faleiro ML. The mode of antibacterial action of essential oils. Science against microbial pathogens: communicating current research and technological advances 2011;2:1143-156.

25. Muchtaridi M, Musfiroh I, Subarnas A, Rambia I, Suganda H, Nasrudin ME. Chemical composition and locomotors activity of essential oils from the rhizome, stem, and leaf of Alpinia malaccencis (Burm F.) of Indonesian Spices. J App Pharm Sci 2014;4(01):052-05 